\title{
CONTROL OF POST-ANAESTHETIC SHIVERING
}

\author{
Shirley T. LIEM, M.D. AND J. ANTonio AldRETE, M.D., M.S.
}

\section{INTRODUCTION}

Post-ANAEsthetic SHIvering in surgical patients consists of muscular tremors and rigidity rendering patients uncontrollably uncomfortable and making monitoring and nursing care difficult. Shivering is associated with several physiological alterations, ${ }^{1,3}$ such as increased oxygen consumption, tachycardia, and heat production. The incidence of shivering varies in the reports by different authors, ranging from 22 per cent to 50 per cent, the difference being mostly due to the anaesthetics used and the type of patients. ${ }^{4,7}$

Several drugs have been used in the treatment of shivering in patients recovering from anaesthesia, though none has been entirely satisfactory. We have undertaken a triple blind study using magnesium sulfate, methylphenidate (Ritalin ${ }^{\otimes}$ ), calcium chloride and a placebo, to compare the effectiveness of these drugs in the treatment of post-anaesthetic shivering.

\section{METHOD}

One person, not otherwise involved in the study, prepared solutions of methylphenidate $20 \mathrm{mg}$, magnesium sulfate $1.0 \mathrm{mg}$, calcium chloride $200 \mathrm{mg}$, and a placebo (normal saline) and each in 2 milliliter volumes. Recovery room personnel were instructed to administer one of these solutions intravenously when shivering was noted as soon as the patient arrived in the recovery room and the vital signs had been recorded. No change in anaesthetic technique or other drug therapy was made while this study was being conducted. The patients included in the study had undergone various types of surgical procedures either under general or regional anaesthesia. Oxygen by a nasal cannula was given in every case at a flow of 6 L. per minute. Rectal temperature and blood pressure were taken before and after the administration of the medication. The patients were observed for cessation of shivering for five minutes after the injection. Each patient was covered with a bedsheet and a thin cotton bedspread. As soon as the patient was arousable, and when the shivering had stopped, subjective information as to how the patient was feeling was obtained by interrogation.

\section{Results}

One hundred and fifty-three patients were included. Of 48 patients treated with magnesium sulfate, 29 (60.4 per cent) stopped shivering. The correlation with the technique of anaesthesia used is shown in Table $I$.

From The Department of Anesthesiology, University of Louisville School of Medicine, Louisville, Kentucky 40202. 
Seventeen out of 42 patients receiving methylphenidate stopped shivering ( 40.4 per cent). Correlation with the techniques of anaesthesia used is shown in Table II.

In the calcium chloride group, shivering was arrested in only 8 out of 23 patients (34.6 per cent), with some variations according to the anaesthetic given (Table III).

Of the 40 patients treated with placebo solution, only seven appeared to have stopped shivering soon after the medication was given (Table IV). Regardless of whether the patients stopped or continued shivering, there were no immediate changes in temperature.

TABLE I

\begin{tabular}{lcccc}
\multicolumn{5}{c}{ Magnesium Sulfate } \\
\hline Anaesthesia & $\begin{array}{c}\text { No. of } \\
\text { Patients }\end{array}$ & Stopped & Continued & \% Effective \\
\cline { 2 - 6 } Inhalation & 26 & 16 & 10 & 61 \\
Regional & 13 & 8 & 5 & 61 \\
Intravenous & 9 & 5 & 4 & 55 \\
Totals & 48 & 29 & 19 & \\
\hline
\end{tabular}

TABLE II

MethylPhenidate

\begin{tabular}{|c|c|c|c|c|}
\hline \multirow[b]{2}{*}{ Anaesthesia } & \multirow{2}{*}{$\begin{array}{l}\text { No. of } \\
\text { Patients }\end{array}$} & \multicolumn{3}{|c|}{ Effect on Shivering } \\
\hline & & Stopped & Continued & $\%$ Effective \\
\hline $\begin{array}{l}\text { Inhalation } \\
\text { Regional } \\
\text { Intravenous } \\
\text { Totals }\end{array}$ & $\begin{array}{r}22 \\
11 \\
9 \\
42\end{array}$ & $\begin{array}{r}11 \\
6 \\
5 \\
17\end{array}$ & $\begin{array}{r}11 \\
5 \\
4 \\
15\end{array}$ & $\begin{array}{l}50 \\
66 \\
55\end{array}$ \\
\hline
\end{tabular}

TABLE III

Calcium Chloride

\begin{tabular}{|c|c|c|c|c|}
\hline \multirow[b]{2}{*}{ Anaesthesia } & \multirow{2}{*}{$\begin{array}{l}\text { No. of } \\
\text { Patients }\end{array}$} & \multicolumn{3}{|c|}{ Effect on Shivering } \\
\hline & & Stopped & Continued & $\%$ Effective \\
\hline $\begin{array}{l}\text { Inhalation } \\
\text { Regional } \\
\text { Intravenous } \\
\text { Totals }\end{array}$ & $\begin{array}{r}14 \\
6 \\
3 \\
23\end{array}$ & $\begin{array}{l}4 \\
3 \\
1 \\
8\end{array}$ & $\begin{array}{r}10 \\
3 \\
2 \\
15\end{array}$ & $\begin{array}{l}28 \\
50 \\
33\end{array}$ \\
\hline
\end{tabular}

TABLE IV

Placebo (Sodium Chloride)

\begin{tabular}{lcccc}
\hline & & \multicolumn{3}{c}{ Effect on Shivering } \\
\cline { 3 - 5 } Anaesthesia & $\begin{array}{c}\text { No. of } \\
\text { Patients }\end{array}$ & Stopped & Continued & \% Effective \\
\hline Inhalation & 16 & 4 & 12 & 25 \\
Regional & 10 & 1 & 9 & 10 \\
Intravenous & 14 & 2 & 12 & 14 \\
Totals & 40 & 7 & 33 & \\
\hline
\end{tabular}


TABLE V

SIDE EFFECTS

\begin{tabular}{lccccc}
\hline & $\mathrm{MgSO}_{4}$ & $\mathrm{MPD}$ & $\mathrm{CaCl}_{\mathbf{z}}$ & Placebo & Total Cases \\
\hline Mild Flushing & 6 & - & 6 & - & 12 \\
Severe Flushing & 1 & - & 12 & - & 13 \\
$\downarrow \mathrm{BP}$ & 1 & - & - & - & 1 \\
$\uparrow \mathrm{BP}$ & - & 4 & 2 & 6 \\
\hline
\end{tabular}

MPD-Methylphenidate

\section{Side Effects}

Facial flushing was the common side-effect seen (Table V), occurring more frequently in the groups of patients treated with calcium chloride and magnesium sulfate. Only a few patients had changes in blood pressure and in one case systolic pressure fell $30 \mathrm{~mm} \mathrm{Hg}$ after the injection of magnesium sulfate. Four patients had elevations of blood pressure greater than 10 per cent after calcium chloride, while there were no other changes in vital signs. No side-effects were observed in the placebo group. No other appreciable untoward side effects were otherwise noted in the entire study.

\section{Discussion}

Several causes have been postulated for post-anaesthetic shivering. ${ }^{1-7}$ Most patients coming out of air-conditioned operating rooms have been exposed to a cooler temperature over a period of time, usually with a portion of the body uncovered during the operation. Under these circumstances a fall in body temperature usually occurs, accompanied by central vasodilation, peripheral vasoconstriction, or heat loss or a combination of all of these. ${ }^{8,9}$ In our study, as well as in previous series, there was no correlation between the patients who shivered and the fall of body temperature below normal range, nor did the temperature increase when the medications given were effective in arresting the tremor. $\mathrm{Lim}^{3}$ postulated that shivering may be a response to altered central or peripheral body temperature control mechanisms. Shivering may also be an antagonistic effect of low anaesthetic concentration. ${ }^{9}$ Brichard and Johnstone ${ }^{12}$ suggested that the so-called "muscular spasticity and tremor" observed during recovery from halothane anaesthesia might be due to the recovery of spinal activity before the upper motor neurons have recovered from the inhibition of anaesthesia. The question remains: why do some patients shiver who have had regional anaesthesia?

Whatever the cause, post-anaesthetic shivering is physiologically undesirable, since it impedes adequate respiratory exchange, as observed by Horvath et al." in patients who had an increase in oxygen consumption, respiratory minute volume and heat production, above the basal requirements.

Prys-Roberts ${ }^{1}$ confirmed that during shivering there was an increase in oxygen consumption and arteriovenous oxygen content difference and in spite of a high cardiac output, peripheral tissue oxygenation was inadequate and accompanied by considerable peripheral vasoconstriction. 
In this study only about 40 per cent of the 153 patients included stopped shivering; magnesium sulfate (60.4 per cent) and methylphenidate ( 40.4 per cent) appeared to be most effective, in that order. No differences were noted in the anaesthetic technique as it related to the effectiveness of any particular treatment of the shivering.

Patients recovering from anaesthesia with uncoordinated muscular tremors are uncomfortable and more difficult to manage. Magnesium sulfate in this study was used mainly because of its vasodilating effect since it produces flushing, sweating, and an intense sensation of warmth in man. ${ }^{10,11}$ The dosage was too small, however, to cause any major alterations in cardiovascular or neuromuscular function.

Calcium chloride was also used because its injection is usually accompanied by peripheral vasodilation and a sensation of warmth. ${ }^{12}$ With the exception of slight increases in blood pressure, the small dosage used in this study did not appear to cause any appreciable consistent cardiovascular changes. Methylphenidate, being a psychomotor stimulant with an effect between that of caffeine and amphetamine, ${ }^{16}$ has a peculiar mode of action, most likely by altering the previously described transient upper motor neurone block. ${ }^{9}$ Finally, the sympathomimetic effect of methylphenidate may have an antagonistic effect on sub-narcotic doses of anaesthetic agents such as halothane.

\section{SUMMARY}

From the data shown here, magnesium sulfate and methylphenidate may be the most effective of the substances tested, in the treatment of post-anaesthetic shivering, though not consistently so. Calcium chloride appears to be the least effective and its use is accompanied by some untoward cutaneous flushing which may be uncomfortable for conscious patients. The mechanisms thus far proposed for shivering appear to be inadequate to explain it in every case and no therapy is completely successful; therefore further investigation of the subject is certainly indicated.

\section{RÉSUMÉ}

D’après les données présentées dans ce travail, le Sulfate de Magnésie et le Méthylphénidate sembleraient les agents les plus efficaces pour traiter le frisson qui suit une anesthésie; cependant leur action est inconstante.

Le Chlorure de Calcium, pour sa part, semble moins efficace et son action s'accompagne d'une vasodilatation cutanée possiblement désagréable pour le malade éveillé.

Les hypothèses jusqu'ici avancées, n'arrivent pas à expliquer ces frissons dans tous les cas, conséquemment, aucune thérapeutique complètement efficace n'est encore disponible. Il y a sûrement lieu de pousser les recherches sur ce sujet.

\section{REFERENCES}

1. Prys-Ronents, C. Postanesthetic shivering. Clinical Anesthesia, M.T. Jenkins, ed. Philadelphia: F.A. Davis Company (1968). 
2. Honvath, S.M., SpURr, G.B., Hutr, B.K., \& Hamilton, L.H. The metabolic cost of shivering. J. Appl. Physiol. 8: 595 (1956).

3. Lim, T.P.K. Central and peripheral control mechanisms of shivering and its effects on respiration. J. Appl. Physiol. 15: 567 (1960).

4. Jones, H.D. \& McLaren, C.A.B. Postoperative shivering and hypoxia after halothane, nitrous oxide and oxygen anesthesia. Brit. J. Anaesth. 37: 35 (1965).

5. Conen, M. An investigation into shivering following anesthesia: a preliminary report. Proc. Roy. Soc. Med. 60: 752 (1961).

6. MoIr, D.D. \& DOYLE, P.M. Halothane and postoperative shivering. Anesth. and Analg. 42: $423(1963)$.

7. Bhichard, G. \& Johnstone, M. The effect of methylphenidate (Ritalin) on post-halothane muscular spasticity. Brit. J. Anesth. 42: 718-721 (1970).

8. O'Connor, J.M. On the mechanism of chemical temperature regulation. Proc. Roy. Soc., London 89: $201(1915,1917)$.

9. Claser, E.M. \& Holmes-Jones, R.V. Initiation of shivering by cooled blood returning from the lower limbs. J. Physiol. 114: 277 (1951).

10. Aldrete, J.A., Zahler, A., \& AtKawa, J.K. Prevention of succinylcholine induced hyperkalaemia by magnesium sulfate. Canad. Anaesth. Soc. J. 17: 477-484 (1970).

11. Hilmy, M.Z. \& Somjen, C.G. Distribution and tissue uptake of magnesium related to its pharmacological effects. Amer. J. Physiol. 214: 406-413 (1968).

12. Goodman, L.S. \& Gilman, A. The Pharmacologic Basis of Therapeutics. Macmillan Company, London, p. 799 ( 1965).

13. MEIER, R., Goss, F., \& Tripon, J. Ritalin, a new synthetic compound with specific central stimulating component. Klin. Wschr. 32: 445 ( 1954$)$. 